\title{
The Effect of Untreated and Enzyme-Treated Commercial Dairy Powders on the Growth and Adhesion of Streptococcus mutans
}

\author{
Rachel Halpin \\ Technological University Dublin, rachel.halpin@tudublin.ie \\ D.B. Brady \\ School of Biomolecular and Biomedical Science, University College Dublin, Ireland. \\ E.D. O'Riordan \\ School of Agriculture, Food Science and Veterinary Medicine, University College Dublin
}

See next page for additional authors

Follow this and additional works at: https://arrow.tudublin.ie/schfsehart

Part of the Food Biotechnology Commons, Food Chemistry Commons, Food Microbiology Commons, and the Food Processing Commons

\section{Recommended Citation}

Halpin, R. et al. (2011) The Effect of Untreated and Enzyme-Treated Commercial Dairy Powders on the Growth and Adhesion of Streptococcus mutans, LWT, Food Science \& Technology, Volume 44, Issue 6, July 2011, Pages 1525-1532. doi:10.1016/j.Iwt.2011.01.025

This Article is brought to you for free and open access by the School of Food Science and Environmental Health at ARROW@TU Dublin. It has been accepted for inclusion in Articles by an authorized administrator of ARROW@TU Dublin. For more information, please contact arrow.admin@tudublin.ie, aisling.coyne@tudublin.ie, gerard.connolly@tudublin.ie.

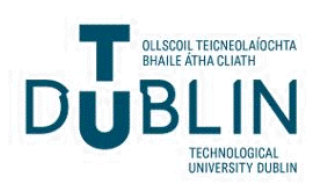




\section{Authors}

Rachel Halpin, D.B. Brady, E.D. O'Riordan, and M. O'Sullivan

This article is available at ARROW@TU Dublin: https://arrow.tudublin.ie/schfsehart/243 
1 The Effect of Untreated and Enzyme-Treated Commercial Dairy Powders on the

2 Growth and Adhesion of Streptococcus mutans

3 R.M. Halpin ${ }^{1 *}$, D.B. Brady ${ }^{2 \S}$, E.D. O’Riordan ${ }^{1}$ and M. O’Sullivan ${ }^{1}$

$4 \quad{ }^{1}$ School of Agriculture, Food Science and Veterinary Medicine, University College

5 Dublin, Ireland.

$6 \quad{ }^{2}$ School of Biomolecular and Biomedical Science, University College Dublin, Ireland.

7 §Present Address: School of Science, Athlone Institute of Technology, Athlone,

8 Ireland.

9 *Corresponding author: Rachel Halpin, School of Agriculture, Food Science and

10 Veterinary Medicine, University College Dublin, Ireland.

11 Tel:0035317161301

12 E-mail address: rachel.halpin@ucd.ie

13

14 Keywords: Streptococcus mutans, dental caries, growth, adhesion, whey.

15

16

17

18

19

20

21

22

23

24

25 


\section{Abstract}

Dental caries is a common bacterial infection, but the progression of this disease can be delayed by preventing initial attachment of cariogenic bacteria such as

29 Streptococcus mutans to tooth surfaces. This study firstly compares the effect of untreated (UT) and enzyme-treated (ET) dairy powders on the adherence of S. mutans to hydroxylapatite (HA), an analogue of tooth enamel. A fluorescence-based method was used to quantify adherence of $S$. mutans to HA both in the presence (S-HA) and absence (PBS-HA) of saliva. Secondly, binding of proteins present in the test materials to HA was quantified using bicinchonic acid assays and SDS-PAGE. In addition, the effect of UT and ET dairy powders on growth of $S$. mutans was examined using an optical-density based assay. UT acid whey protein concentrate (WPC) 80, sweet WPC80, buttermilk powder (BMP) and cream powder (CP) significantly $(P<0.05)$ inhibited adhesion of $S$. mutans at $\geq 31.25 \mu \mathrm{g} \mathrm{mL} \mathrm{m}^{-1}$ in the presence and absence of saliva. ET dairy powders were less effective inhibitors of adhesion, but ET sweet WPC80 significantly $(P<0.05)$ inhibited growth of $S$. mutans at $\geq 0.6 \mathrm{mg} \mathrm{mL}^{-1}$. Therefore, due to their adherence- and growth-inhibitory properties, dairy powders may be beneficial in the treatment of dental caries.

43 


\section{Introduction}

Dental caries affects both children and adults, and is regarded as one of the most common bacterial infections in humans (Aas, Paster, Stokes, Olsen, \& Dewhirst, 2005). Individuals are susceptible to this disease throughout their lifetime (Sewitz, Ismail, \& Bitts, 2007). Streptococcus mutans is considered to be the primary etiological agent involved in formation of dental caries (Loesche, 1986). Once adhered to the buccal surfaces, acid(s) formed by oral bacteria due to fermentation of sugars accumulate in plaque on the teeth, and in turn contribute to tooth decay (Loesche, 1986). Adhesion of a pathogenic microorganism to a host tissue is considered to be a vital step in colonisation and subsequent infection (Finlay and Falkow, 1997). Over 25 years ago, Beachey (1981) proposed the design of therapies to prevent initial adherence of a pathogen to surface receptors, thus blocking the prerequisite step of infection. Therefore, a logical approach to preventing initiation of the dental caries process centres upon inhibiting the adherence of cariogenic bacteria such as S. mutans to the tooth surface (Tarsi, Muzzarelli, Guzman, \& Pruzzo, 1997). Many effective anti-adhesion agents have been identified in foods and beverages (Ofek, Hasty, \& Sharon, 2003), such as herbal extracts (Limsong, Benjavongkulchai, \& Kuvatanasuchati, 2004), cranberry juice (Yamanaka, Kimizuka, Kato, \& Okuda, 2004), and water-soluble protein fraction (WSPF) from hen egg yolk (Gaines, James, Folan, Baird, \& O’Farrelly, 2003). In addition, some constituents of human milk are known to be capable of binding to pathogenic microbes and inhibiting their adherence to host surfaces (Ofek et al., 2003). It is possible that the equivalent components of bovine milk (and products thereof) could have similar anti-adhesion effects. 
considerable interest as it has become evident that many of its constituents exhibit bioactive properties (Marshall, 2004). Whey protein is made up of $\beta$-lactoglobulin (50\%), $\alpha$-lactalbumin (20-25\%), bovine serum albumin (10-15\%), immunoglobulins (10-15\%), lactoferrin (0.35 to 2\%) and lactoperoxidase (0.25-0.5\%) (Madureira, Pereira, Gomes, Pintado, \& Malcata, 2007). Also, sweet whey contains glycomacropeptide (GMP) at concentrations of up to 15\% (Madureira et al., 2007). Peptides derived from these precursor proteins are known to have antibacterial properties (Madureira et al., 2007), with enzymatic digestion being the most common method used to produce such peptides (Kurhonen, 2009). In addition, it has been reported that peptides possessing antibacterial activity can also exhibit other biological activities relating to protection of the host (Lopez-Exposito \& Recio, 2006). Peptide-based therapeutic agents from natural substrates (such as dairy products) that can be added to food, toothpaste and mouthrinses are increasingly in demand as an approach to delay progression of caries (Hayes, Ross, Fitzgerald, Hill, \& Stanton, 2006).

A non-protein constituent of whey which may contribute to its bioactive properties is milkfat. This component may also have potential to inhibit dental caries, as it contains triglycerides and lipids that can exhibit antimicrobial effects either directly or following enzymatic digestion (Sprong, Hulstein, \& van der Meer, 2002). The spectrum of saturated fatty acids in milkfat can vary in chain-length from $\mathrm{C}_{4}$ to $\mathrm{C}_{18}$, while also containing the unsaturated fatty acids $\mathrm{C}_{18: 1}$ and $\mathrm{C}_{18: 2}$ (Sprong, Hulstein, \& van der Meer, 2001). It has been reported that the medium-chain fatty acids $C_{8}$ $\mathrm{C}_{12}$ can have a bacteriostatic effect on dental plaque bacteria (Schuster, 1980). commercial dairy powders (including whey products such as whey protein 
101 concentrates and whey protein isolates, along with buttermilk powder and cream 102 powder) are capable of inhibiting adherence of S. mutans to hydroxylapatite (HA) 103 (Halpin et al., 2008). HA is a calcium-phosphate analogue of teeth commonly used as 104 an in vitro model (Gibbons, Moreno, \& Spinell, 1976, Clark \& Gibbons, 1977, Gaines 105 et al., 2003) of adherence of oral bacteria to tooth surfaces. Also, it has been claimed 106 that a commercial whey product (Carbelac 80) can inhibit both growth and adherence 107 of S. mutans following treatment with porcine pancreatic lipase (PPL) (Brady \& 108 Folan, 2003). Further to this, a separate study by Halpin, Brady, O’Riordan, \& 109 O’Sullivan (2009) showed a range of commercial whey products reduced association 110 of enteric pathogens to CaCo-2 cells, and that the anti-adherence effect was enhanced 111 following PPL-treatment of the whey products. As whey contains both protein and fat, enzymatic digestion can potentially

113 liberate an array of peptides and fatty acids, respectively. In the present study, a varied 114 range of whey and dairy products which were previously found to effectively reduce 115 adherence of S. mutans to phosphate-buffered saline-coated HA (PBS-HA) (Halpin et 116 al., 2008) were subjected to enzyme-treatment in order to determine if this would 117 increase their anti-adhesion activity. Therefore, the main objective of the present 118 study was to examine the effect of enzyme-treatment on the anti-adhesion efficacy of 119 these dairy powders, using both PBS-HA and saliva-coated HA (S-HA). Association 120 of the proteinaceous component of a selection of dairy powders to HA beads was also 121 investigated. In addition, the effect of both untreated and enzyme-treated dairy 122 powders on the growth of $S$. mutans was examined.

123 2. Materials and Methods

\section{$124 \quad 2.1$ Bacterial Isolates and Growth Conditions}


125 A clinical isolate of S. mutans (LAN-SVHERC-1997sm1) was obtained from the 126 Microbiology Department, St. Vincent’s University Hospital, Dublin, Ireland. 127 Bacteria were maintained on Protect ${ }^{\mathrm{TM}}$ Bacterial Preserve beads (Technical Service 128 Consultants Ltd, Lancashire, UK) at $-80^{\circ} \mathrm{C}$. A single bead from the frozen stock 129 culture was used to inoculate a Columbia blood agar plate (CBA: Oxoid, Hampshire, 130 England) and grown aerobically at $37^{\circ} \mathrm{C}$ for $48 \mathrm{~h}$. A single colony from the blood agar 131 plate was subsequently used to inoculate $20 \mathrm{~mL}$ of brain heart infusion (BHI) broth 132 (LabM, Lancashire, UK) and grown under aerobic conditions without shaking at $37^{\circ} \mathrm{C}$ 133 for $18 \mathrm{~h}$.

\section{$134 \quad 2.2$ Source and Characterisation of Dairy Powders}

135 Sweet whey protein concentrate 80 (SWPC80), acid WPC 80 (AWPC80), sweet WPC 13635 (SWPC35), whey protein isolate (WPI), whey powder (WP) and demineralised 137 whey (DW) powders were supplied by Carbery Milk Products (Ballineen, Cork, 138 Ireland). The principal differences in composition between SWPC80 and SWPC35 139 should be noted. Although both of these whey products are derived from sweet whey, 140 SWPC80 contains $80 \%$ protein (i.e. 80 grams of protein per $100 \mathrm{~g}$ of product) and only $1416 \%$ lactose (i.e. 6 grams of lactose per 100g of product). However, SWPC35 contains 142 almost 35\% protein and approximately 51\% lactose. In addition, SWPC35 contains 143 only half of the amount of fat that is present in SWPC80 (refer to Table 1).

144 Buttermilk powder (BMP) and cream powder (CP) were supplied by Kerry Group plc 145 (Tralee, Co. Kerry, Ireland). Albumin from chicken egg white (grade V) and lactose 146 were supplied by Sigma (Poole, Dorset, UK).

147 Compositional analysis was performed on each dairy product using standard methods. 148 Ash content was analysed according to Malkomesius \& Nehring (1951). Fat content 149 was determined according to the method of Röse-Gottlieb (International Dairy 
150 Federation, IDF, 1987), protein content was determined by the Kjeldahl method (IDF,

151 1993a) and the moisture content was determined by the IDF reference method (IDF, 152 1993b).

\section{$153 \quad 2.3$ Hydrolysate Preparation Conditions}

154 Crude porcine pancreatic lipase (PPL, 100-400 units/ mg protein) (Sigma, Poole,

155 Dorset, England) was used throughout the study. Preliminary experiments

156 demonstrated the presence of both peptidase and lipase activities in this enzyme

157 preparation (data not shown). Hydrolysates were prepared in a Fermac 200 fermentor

158 (Electrolab Ltd, Tewkesbury, UK) as follows: a c. 2\% (g/100mL) solution of substrate

159 was prepared by dissolving $20 \mathrm{~g}$ of dairy powder in $900 \mathrm{~mL}$ of sterile distilled water 160 and heating at $37^{\circ} \mathrm{C}$ with stirring for $30 \mathrm{~min}$. Lipase solution $(1 \mathrm{~g}$ of PPL in $100 \mathrm{~mL}$ of 161 sterile $\mathrm{H}_{2} 0$ ) was added to the substrate solution to give a final incubation volume of 1

162 L. The substrates were then incubated for $18 \mathrm{~h}$ at $37^{\circ} \mathrm{C}$ with stirring. The resulting 163 hydrolysates were heated at $60^{\circ} \mathrm{C}$ for $10 \mathrm{~min}$ in order to denature the enzyme(s). Each 164 hydrolysate was then placed on ice and allowed to cool to less than $10^{\circ} \mathrm{C}$ (approx. 45 $165 \mathrm{~min}$ ), before being frozen using liquid nitrogen and subsequently lyophilised 166 (Moduloyo, Edwards High Vacuum, Manor Royal, Crawley, Sussex, UK).

\subsection{Adhesion Assay}

\subsection{1 (a) Preparation of Hydroxylapatite}

169 Hydroxylapatite (HA) beads were supplied by Merck (Darmstadt, Germany). Both

170 phosphate buffered saline-coated and saliva-coated HA were used throughout the 171 study. Particle size analysis using a Malvern Mastersizer (Malvern Instruments Ltd., 172 Worcestershire, UK) showed the average diameter ( $D[4,3])$ of the HA beads to be 173 approximately $10 \mu \mathrm{m}$. Phosphate-buffered saline coated HA (PBS-HA, PBS: Oxoid, 
174 Hampshire, England) was prepared by suspension of $7.5 \mathrm{mg} \mathrm{mL}^{-1} \mathrm{HA}$ in PBS

175 immediately before use in the adherence assays.

176 Saliva-coated-HA (S-HA) was prepared by a modification of the protocol set out by

177 Gibbons \& Etherden (1982) as follows: parafilm-stimulated whole saliva was

178 collected in an ice-chilled tube from two healthy donors ( 1 male, 1 female) at least $1 \mathrm{~h}$

179 after eating, drinking or brushing of teeth. The saliva was heated at $60^{\circ} \mathrm{C}$ for $30 \mathrm{~min}$ to

180 inactivate degenerative enzymes, and subsequently centrifuged at $12,000 \times \mathrm{g}$ for 15

181 min. The pellet was discarded and the supernatant (i.e. clarified whole saliva) was

182 used to prepare a $7.5 \mathrm{mg} \mathrm{mL}^{-1}$ dispersion of HA. Aliquots $(150 \mu \mathrm{L})$ of saliva-coated

183 hydroxylapatite (S-HA) were dispensed into the wells of a 96-well V-bottomed plate

184 (Sarstedt, Newton, North Carolina, USA), and incubated at $30^{\circ} \mathrm{C}$ for $1 \mathrm{~h}$ with gentle

185 agitation $(4.5 \times \mathrm{g})$. Following this, the microtitre plate was centrifuged at $805 \times \mathrm{g}$ for

1862 min, the supernatants discarded and the S-HA pellets washed twice with sterile pre-

187 warmed PBS to remove excess saliva. The S-HA pellets were subsequently

188 resuspended in sterile PBS for use in the adherence assay.

\section{$189 \quad 2.4 .1$ (b) Preparation of Syto ${ }^{\circledR} 13$ dye}

190 Syto ${ }^{\circledR} 13$ dye (Molecular Probes, Oregon, USA) was supplied as a $5 \mathrm{mmol} \mathrm{L}^{-1}$ 191 solution in dimethylsulphoxide (DMSO). This concentration was adjusted to $5 \mu \mathrm{mol} \mathrm{L}^{-}$

$192{ }^{1}$ by appropriate dilution in sterile PBS, and was used only on the day of preparation.

193 A standard curve of relative fluorescent units (RFU) versus CFU mL ${ }^{-1}$ was 194 constructed for $S$. mutans $\left(\mathrm{R}^{2}=0.9942\right)$.

\section{$195 \quad$ 2.4.2 Assay Protocol}

196 An overnight culture of S. mutans was centrifuged at $3220 \times \mathrm{g}$ (Eppendorf 5810R, 197 Cambridge, UK) for $10 \mathrm{~min}$ and the pellet resuspended in sterile PBS. Following a 198 second centrifugation step, the bacterial pellet was resuspended in PBS, and the 
199 OD $_{630 \mathrm{~nm}}$ of the suspension measured using a Multiskan Ascent spectrophotometer 200 ((Thermo Electron Corporation, Vantaa, Finland), and adjusted to 0.2 by appropriate 201 dilution with sterile PBS.

202 The adherence assays were carried out as previously described (Halpin et al., 2008), 203 using sterile 96-well polystyrene microtitre half-area plates (Nunc, Roskilde, 204 Denmark). Dairy powders were prepared to the required concentration by dispersing 205 the dried powder in PBS. Briefly, $50 \mu \mathrm{L}$ of test material solution at various 206 concentrations was added to the wells, followed by $50 \mu \mathrm{L}$ of PBS-HA or S-HA (7.5 $\left.207 \mathrm{mg} \mathrm{mL} \mathrm{m}^{-1}\right)$. Bacterial suspension $(50 \mu \mathrm{L})$ was added to the wells, so that the final 208 volume of each well was $150 \mu \mathrm{L}$. Control wells (no bacteria and/ or no HA) were 209 included in each assay. The plate was incubated at room temperature for $45 \mathrm{~min}$, and 210 manually inverted at 5 min intervals to prevent settling of the HA suspension. The 211 plate was subsequently centrifuged at $201 \times \mathrm{g}$ to sediment the HA and any adhering 212 bacteria, leaving the non-adhering bacteria in suspension. These non-adhering bacteria 213 were labelled with $10 \mu \mathrm{L}$ of $5 \mu \mathrm{mol} \mathrm{L} \mathrm{L}^{-1}$ Syto ${ }^{\circledR}$ fluorescent dye. For more information 214 regarding the development and validation of the assay described here, the reader 215 should refer to Halpin et al., 2008.

\subsection{Quantification of Bacterial Adherence}

217 Aliquots $(100 \mu \mathrm{L})$ of supernatant from the adherence assay (Section 2.4.2) containing 218 the non-adhering bacteria were transferred from each well of the half-area plate to the 219 corresponding wells of a black microtitre plate (Costar, Corning Inc., Corning, USA). 220 This plate was allowed to stand at room temperature for $5 \mathrm{~min}$ in the dark before 221 reading the fluorescence using a Fluoroskan Ascent plate reader (Thermo Electron 222 Corporation, Vantaa, Finland). The excitation wavelength was $485 \mathrm{~nm}$ and the 223 emission intensity was monitored at $538 \mathrm{~nm}$. Three measurements were taken at 5 min 
224 intervals, and the average fluorescence calculated. The fluorescence due to the total 225 number of bacteria present in the supernatant was determined as a direct readout from 226 the fluorimeter as relative fluorescent units (RFU). The background fluorescence due 227 to non-bacterial components of the assay (i.e. dairy powder and HA) were subtracted. 228 The percentage inhibition of adhesion was calculated as follows:

$$
\frac{(\text { Fluorescence due to unbound bacteria })}{(\text { Fluorescence due tototal input bacteria })} \times 100
$$

\subsection{Protein Adherence Assay}

The ability of the proteinaceous component of the various dairy powders to adhere to the HA beads was assessed as follows; a dispersion of HA (20 mg mL $\left.{ }^{-1}\right)$ was mixed with an equal volume of test material at various concentrations, so that the final concentration of test material ranged from $0.0625 \mathrm{mg} \mathrm{mL}^{-1}$ to $1 \mathrm{mg} \mathrm{mL}^{-1}$. The mixture was gently inverted at $5 \mathrm{~min}$ intervals for a period of $45 \mathrm{~min}$, before being centrifuged (201 × g, $10 \mathrm{~min})$. Supernatants were subsequently decanted into plastic tubes and shaken vigorously before determination of protein content by the bicinchonic acid (BCA) method (Smith et al., 1986), for which all reagents were supplied by Sigma (Poole, Dorset, UK). Aliquots $(25 \mu \mathrm{L})$ of supernatant were added to wells of a 96-well plate, followed by $200 \mu \mathrm{L}$ of BCA reagent, and the plate was subsequently incubated for 30 min at $37^{\circ} \mathrm{C}$. A plate reader (Spectra Max; Molecular Devices Corp., U.K.) was used to measure sample absorbance values. Absorbance was measured at 570nm $\left(\mathrm{Abs}_{570 \mathrm{~nm}}\right)$, and readings were converted to $\mathrm{mg} \mathrm{mL}^{-1}$ protein using a standard curve of absorbance versus protein concentration $\left(\mathrm{R}^{2}=0.9983\right)$, which was prepared using bovine serum albumin (BSA; Sigma, Poole, Dorset, UK).

\subsection{Sodium dodecyl sulphate polyacrylamide gel electrophoresis (SDS-PAGE)}


To investigate the selectivity of any HA/ protein interactions, the protein profiles of

248 the resulting supernatants from the protein adherence assay were compared to that of

249 the starting material by SDS-PAGE (Laemmli, 1970) using the Bio-Rad protein mini-

250 gel system (Bio-Rad Laboratories, Richmond, California). Briefly, this was achieved

251 by incubating untreated WPCs with HA beads or alone (as described in Section 2.6).

252 Sedimentation recovered the HA beads along with any bound protein, leaving 253 unbound protein in the supernatant which was quantified using SDS-PAGE. All 254 reagents were purchased from Sigma (Poole, Dorset, UK). Resolving gel and stacking 255 gel were prepared to $15 \mathrm{~g} / 100 \mathrm{~mL}$ and $4 \mathrm{~g} / 100 \mathrm{~mL}$ acrylamide, respectively. In order to 256 visualise protein bands, gels were stained using coomassie blue dye. Protein bands 257 were quantified using densitometry software (Alphaview Version 1.3.0.7, Innovatech 258 Corporation).

\subsection{Growth Assays}

260 Growth assays were carried out in sterile 96-well plates (Nunc, Roskilde, Denmark).

261 Overnight cultures of $S$. mutans were prepared in BHI broth as described earlier 262 (Section 2.1). A working culture containing c. $10^{8}$ colony forming units per millilitre 263 (CFU $\mathrm{mL}^{-1}$ ) was prepared by adding $1 \mathrm{~mL}$ of overnight culture to $9 \mathrm{~mL}$ of sterile $\mathrm{BHI}$ 264 broth. Test materials were prepared by dispersing dried dairy powders or hydrolysates 265 in BHI broth to the desired concentration. Aliquots $(100 \mu \mathrm{L})$ of test material were 266 added to the wells of the plate, followed by $100 \mu \mathrm{L}$ of the diluted culture; the final 267 concentrations of test material were $0.6 \mathrm{mg} \mathrm{mL}^{-1}, 1.25 \mathrm{mg} \mathrm{mL}^{-1}, 2.5 \mathrm{mg} \mathrm{mL}^{-1}$ and $5 \mathrm{mg}$ $268 \mathrm{~mL}^{-1}$. Bacterial growth in the absence of test material (i.e. control growth) was also 269 determined. The plate was then incubated at $37^{\circ} \mathrm{C}$ for $18 \mathrm{~h}$ in a Multiskan Ascent plate 270 reader (Thermo Electron Corporation, Vantaa, Finland). Immediately prior to 271 incubation the plate was shaken for $1 \mathrm{~min}$ in order to disperse the suspensions. The 
optical density (OD) readings at $630 \mathrm{~nm}$ for each well were subsequently recorded at 1

$273 \mathrm{~h}$ intervals, with the plate being shaken for $30 \mathrm{~s}$ immediately prior to measurement.

274 The initial OD reading, recorded at time 0 , of each well was subtracted from all other

275 readings for the corresponding wells over the $18 \mathrm{~h}$ incubation time (i.e. to subtract the

276 background OD values).

2.9 Solid Phase Micro Extraction / Gas chromatography (SPME/GC) headspace analysis of short chain fatty acids (SCFAs)

SPME/GC analysis was performed in order to confirm the presence of the free fatty acids butanoic $\left(\mathrm{C}_{4}\right)$ and hexanoic $\left(\mathrm{C}_{6}\right)$ in SWPC80 post-hydrolysis with PPL. This 281 was carried out according to the method of Noronha, Cronin, O’Riordan, \& 282 O’Sullivan (2008). Briefly, GC analysis was performed on an ATI Unicam Model 2836100 gas chromatograph fitted with a flame ionisation detector (FID) and interfaced to a Spectra-Physics SP4290 computing integrator. The column used was a $15 \mathrm{~m}$ FFAP (Quadrex Inc.) fused silica column $(0.53 \mathrm{~mm}$ i.d., film thickness, $1 \mu \mathrm{M})$. Hydrogen was used as a carrier gas at a flow rate of $8 \mathrm{~mL} \mathrm{~min}^{-1}$. The column 287 temperature was $140^{\circ} \mathrm{C}$ and the injection block was set at $300{ }^{\circ} \mathrm{C}$. The volatile SCFAs $288\left(\mathrm{C}_{4}\right.$ and $\left.\mathrm{C}_{6}\right)$ present in the aqueous dairy powder hydrolysate $\left(20 \mathrm{~g} \mathrm{~L}^{-1}\right)$ samples were 289 measured by SPME headspace analysis using iso-butanoic (iso- $\mathrm{C}_{4}$ ) and 4-methyl290 pentanoic acids (4-Me- $\mathrm{C}_{5}$ ) as internal standards (IS), respectively, at various time291 points after addition of the PPL. The SPME fibres (Carboxen/ PDMS, 75 $\mu \mathrm{M}$ 292 thickness) were obtained from Supelco (Supelco-Aldrich, Dublin, Ireland) and were 293 conditioned under a flow of nitrogen $\left(10 \mathrm{~mL} \mathrm{~min}^{-1}\right)$ at $300^{\circ} \mathrm{C}$ for $2.5 \mathrm{~h}$ prior to use.

294 An aliquot $(20 \mathrm{~mL})$ of the hydrolysate was transferred to a $10 \mathrm{~mL}$ screw thread glass 295 vial, fitted with a magnetic stirring bar. After sealing the vial with a 296 polytetrafluoroethylene (PTFE) silicone rubber septum, the SPME needle was 
inserted through the latter so as to position the fibre $15 \mathrm{~mm}$ above the surface of the liquid hydrolysate. The hydrolysate was heated with stirring by placing the vial in a thermostatically controlled water bath at $50^{\circ} \mathrm{C}$. After equilibration for $10 \mathrm{~min}$, the headspace was sampled by exposing the fibre for $10 \mathrm{~min}$. The concentration of the volatile fatty acids (VFAs) was determined using the following equation:

$$
=\frac{\text { peak area of analyte } \times \text { concentration IS }}{\text { peak area of IS } \times \text { response factor } \times \text { sample volume }}
$$

305 The response factors for the two analytes were established by carrying out SPME 306 headspace analysis of an aqueous standard $\left(0.2 \mathrm{~g} \mathrm{~L}^{-1}\right.$ each of $\mathrm{C}_{4}$, iso- $\mathrm{C}_{4}, \mathrm{C}_{6}$ and $4-\mathrm{Me}-$ $\mathrm{C}_{5}$ acids) under the same conditions as described above for the liquid hydrolysate samples.

$$
\text { Response factor }\left(\mathrm{C}_{4} \text { or } \mathrm{C}_{6}\right)=\frac{\text { peak area } \mathrm{C}_{4}}{\text { peak area iso- } \mathrm{C}_{4}} \text { or } \frac{\text { peak area } \mathrm{C}_{6}}{\text { peak area } 4-\mathrm{Me}-\mathrm{C}_{5}}
$$

310 The response factor was calculated as 1 for both $\mathrm{C}_{4}$ and $\mathrm{C}_{6}$. GC retention times of the

311 SCFAs were 2.2, 2.8, 5.6 and 6.6 min for iso- $\mathrm{C}_{4}, \mathrm{C}_{4}, 4-\mathrm{Me}-\mathrm{C}_{5}$ and $\mathrm{C}_{6}$, respectively.

\subsection{Statistical Analysis}

313 All adherence/ growth assays were performed at least three times $(n=3)$. Results were

314 expressed as the mean \pm standard deviation (S.D.). Differences between 315 concentrations within treatments were determined using the least significant 316 difference (LSD) test, while differences between treatments were determined using 317 Duncan's test. Both analyses were performed using SAS Version 9.1.3. Data were 318 considered significantly different if $P<0.05$. 


\section{Results}

320 Compositional analysis of the dairy powders (fat, protein, moisture, ash and lactose)

321 was determined (Table 1). These were typical of their product types. Sweet and acid 322 WPC80s have similar protein and fat contents, while WPI has almost no fat. WP and 323 DW contain less protein and fat than the WPCs and WPI, but have a high content of 324 lactose. SWPC35 also contains high levels of lactose when compared to the 325 WPC80's, WPI and CP. BMP contained less protein than the WPCs and WPI, and CP 326 had the highest fat content of the test materials.

\subsection{Adherence Assays}

(a) Adhesion to phosphate buffered saline-coated hydroxylapatite

329 A small proportion of S. mutans did not bind to PBS-HA (c. 15\%) under our 330 experimental conditions (shown as the 'control' value in Table 2). Of the untreated 331 dairy powders, AWPC80 appeared to be the most effective inhibitor of S. mutans 332 adhesion to PBS-HA at the concentrations examined (Table 2), increasing the non333 binding proportion of bacteria to c. $93 \%$. However, at $125 \mu \mathrm{g} \mathrm{mL}^{-1}$, UT BMP and UT 334 CP were equally as effective $(P>0.05)$. The protein control, egg albumin, did not 335 reduce adhesion at all, and resulted in similar non-binding proportions of S. mutans as 336 were observed in the absence of test material (i.e. control adherence).

337 In most cases, enzyme treatment was found to reduce the anti-adhesion activity of all 338 dairy powders (Table 2), in that the proportion of non-binding bacteria was markedly 339 lower for the ET dairy powders than those observed for the equivalent UT samples. At $340125 \mu \mathrm{g} \mathrm{mL}^{-1}$, enzyme treatment significantly $(P<0.05)$ reduced the anti-adhesion 341 activity of all dairy powders with the exception of WP. None of the enzyme-treated 342 dairy powders caused the non-binding proportion of $S$. mutans to increase to levels $343 \geq 40 \%$ in the PBS-HA assays. ET CP was the most potent inhibitor of S. mutans 
344 adhesion to PBS-HA at $31.25 \mu \mathrm{g} \mathrm{mL}^{-1}$, and ET CP and ET SWPC80 were found to be

345 equally as effective $(P>0.05)$ inhibitors at $62.5 \mu \mathrm{g} \mathrm{mL}^{-1}$ and $125 \mu \mathrm{g} \mathrm{mL}^{-1}$.

346 Lactose, which was present in all test materials at varying levels, was not found to 347 affect adherence of $S$. mutans to PBS-HA, even when used at concentrations up to $3481000 \mu \mathrm{g} \mathrm{mL} L^{-1}$ (data not shown), and in fact was found to significantly increase the 349 adherence of $S$. mutans to PBS-HA $(P<0.05)$.

(b) Adhesion to saliva-coated hydroxylapatite

351 In the presence of saliva, the control level of adhesion of S. mutans to hydroxylapatite 352 was significantly reduced when compared to that of the PBS-HA model $(P<0.0001)$, 353 with c. 37\% of each bacterial culture not adhering to S-HA ('control' in Table 3).

354 At concentrations $\geq 31.25 \mu \mathrm{g} \mathrm{mL}^{-1}$, UT SWPC80, AWPC80 and BMP significantly $355(P \leq 0.05)$ reduced adherence of $S$. mutans to S-HA relative to the protein control (egg

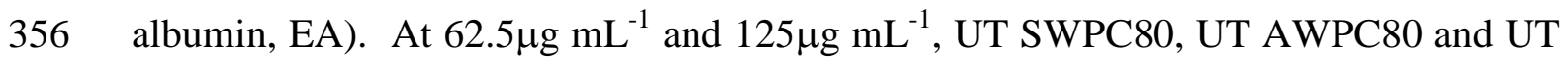
357 WP were the most potent inhibitors of $S$. mutans adhesion to S-HA, being more 358 effective than all other UT test materials and increasing the proportion of non-binding 359 bacteria to $75-80 \%$.

360 Consistent with our observations in the PBS-HA model system, untreated dairy 361 powders were generally more potent inhibitors of $S$. mutans adherence than the same 362 powders following enzyme-treatment, except in the case of the WPCs, which were 363 found to show similar levels of efficacy both in their untreated and enzyme-treated 364 forms. However, it is worthwhile to note that the reduction in anti-adhesion activity 365 caused by enzyme treatment of powders was not as dramatic in the case of S-HA as 366 that observed in the PBS-HA model. Following enzyme treatment, at $31.25 \mu \mathrm{g} \mathrm{mL}^{-1}$, 367 all powders excluding ET WPI, ET WP and ET DW significantly inhibited adherence 368 of $S$. mutans to S-HA relative to the control $(P<0.05)$. However, at $125 \mu \mathrm{g} \mathrm{mL}^{-1}$, all 
enzyme treated dairy powders were more effective than egg albumin $(P<0.05)$, with most ET dairy powders showing similar levels of anti-adhesion.

\subsection{Adherence of Whey and Dairy Powders to PBS-HA}

The more effective inhibitors of $S$. mutans adherence to PBS-HA were used to establish if protein present in the test material was adhering to the HA beads. Table 4 shows the relationship between the initial protein concentrations of these dairy suspensions and the amount of protein associated with HA. When sedimented from solutions of increased protein content, the amount of protein associated to the HA increased with increasing protein concentration in all cases, but to different extents, perhaps suggesting dairy powders possessed different affinities for HA. Of the materials examined, the greatest level of protein association was observed in the case of AWPC80, which was also observed to be the most potent inhibitor of S. mutans adherence to PBS-HA (Table 2).

\subsection{SDS-PAGE of Protein Content of WPC Supernatants Before and After}

\section{Incubation with PBS-HA}

The electrophoresis patterns of UT SWPC80, UT AWPC80 and UT SWPC35 before and after incubation with and separation from HA are compared in Figure 1. Densitometric analysis of the protein bands confirmed that the total protein content of each WPC was reduced following incubation with HA. Protein contents of UT SWPC80, UT AWPC80 and UT SWPC35 were reduced by 66.7\%, 53.9\% and 59.4\%, respectively. Most notably, the larger proteins (possibly the heavy and light chains of the immunoglobulins and BSA) appeared to have associated with HA, as these bands are not present following incubation with HA.

In addition, densitometric analysis indicated that the protein bands representing $\beta$-lac were reduced by 51\%, $41 \%$ and $63.2 \%$ for UT SWPC80, UT AWPC80 and UT 
394

395

396

397

398

399

400

401

402

403

404

405

406

407

408

409

410

411

412

413

414

415

416

417

SWPC35, respectively. No reduction in intensity was observed for the bands representing $\alpha$-lac following incubation with HA, suggesting this whey protein did not adhere to the HA beads.

\subsection{Growth Inhibition Assays}

None of the untreated (UT) dairy powders inhibited growth of $S$. mutans at any of the concentrations examined (0.6-5 $\mathrm{mg} \mathrm{mL}^{-1}$ ) (data not shown). Of the ET dairy powders, growth inhibition of S. mutans was most evident for ET SWPC80 (Figure 2). Growth of $S$. mutans was significantly inhibited $(P<0.05)$ at all concentrations examined, and the effect showed a slight concentration dependency Comparison of the rates of increase of $\mathrm{OD}_{630}$ during the logarithmic growth phase suggests that the maximum concentration of ET SWPC80 (5mg mL $\left.{ }^{-1}\right)$ used reduced the rate of growth by more than 2-fold over that of the control.

\subsection{Determination of Volatile Fatty Acids in ET SWPC80}

Aqueous hydrolysate samples were taken at 15 min intervals following addition of lipase solution and SPME/GC performed at each time point. Levels of $\mathrm{C}_{4}$ and $\mathrm{C}_{6}$ appeared to 'level off' after c. $60 \mathrm{~min}$, and were present at levels of $52.28 \pm 6.68 \mu \mathrm{g}$ $\mathrm{mL}^{-1}$ and $18.66 \pm 1.49 \mu \mathrm{g} \mathrm{mL}^{-1}$, respectively, after $120 \mathrm{mins}$ of hydrolysis time.

\section{Discussion}

The findings of a previous study by this group showed that a range of UT dairy powders reduced adherence of S. mutans to PBS-HA (Halpin et al., 2008). The present study examined the effect of enzyme-treatment on the anti-adhesion activity of these powders, using two model systems: PBS-HA and S-HA. The S-HA model represents the closest approximation to conditions in the oral cavity, while the PBS model system represents a cleaner working matrix and may also serve as a model for 
in vivo conditions where saliva production is impaired, e.g. in cases of 'dry mouth'.

419 Dry mouth, also referred to as xerostomia, describes a variety of conditions whereby 420 salivary flow rate is reduced, and individuals with this condition are susceptible to 421 rampant caries (Loesche, 1986). The authors do however acknowledge that dry 422 mouth patients do not have teeth free from a protein film (so called 'pellicle') and 423 bacterial biofilm, but that the proteins adhering to the tooth tissues are of origins other 424 than saliva, i.e. gingival pockets, exudate from the soft tissues, and of course, foods.

425 Under our experimental conditions, control adherence varied greatly between PBS426 HA and S-HA, which resulted in a different 'starting point' as such for assessing the 427 efficacy of the test materials. The more effective test materials (UT AWPC80, UT 428 SWPC80, UT BMP and UT CP) increased the proportion of S. mutans not adhering to 429 PBS-HA to a level similar to or greater than those observed in the presence of saliva. 430 For example, control adherence of S. mutans was typically $40 \%$ for S-HA, and the 431 proportion of bacteria not adhering to PBS-HA far exceeded this value in the presence 432 of the dairy powders listed above. Thus, dairy powders may be useful ingredients in 433 the development of a beverage which could potentially act as a saliva substitute. It has 434 previously been reported (Johansson, 2002) that milk and dairy-based drinks possess 435 many of the biological and physical attributes that would make them suitable saliva 436 substitutes, and the current investigation provides substantiating evidence that this 437 may be a useful application for dairy products.

438 Experiments have shown that proteins present in these dairy powders are 439 interacting with the HA beads and this may, in part at least, be contributing to the 440 reduction in adherence of $S$. mutans to PBS-HA. This observation was confirmed by 441 results from SDS-PAGE, which further suggested that some of the larger proteins in 442 the WPCs such as the immunoglobulins and BSA had associated with the HA beads. 
443 Of the UT dairy powders, AWPC80 was found to be the most effective inhibitor of $S$. 444 mutans adhesion to HA, and exhibited the highest level of protein association with 445 HA beads. However, the level of protein associating with HA varied between test 446 materials, and a high protein content did not necessarily lead to higher levels of 447 interaction with HA beads, suggesting other factors were contributing to inhibition of 448 adherence. Furthermore, it is possible that the test materials are also interacting with 449 the bacterial cells, and this may in turn reduce the ability of the cells to adhere to 450 surfaces.

Although UT AWPC80, UT SWPC80, UT BMP and UT CP were found to be 452 very effective inhibitors of $S$. mutans adherence to both PBS-HA and S-HA, the active 453 component(s) of each of these test materials may not be the same. To begin with, the 454 compositions of these dairy powders are quite different, and this may have had a direct influence on their level of anti-adhesion activity. The inhibitory effect may even be due to multiple factors acting synergistically within a particular test material. Also, 457 these dairy powders exhibited varying levels of efficacy depending on (a) whether 458 they were used in PBS-HA or S-HA systems and (b) whether they had been subjected 459 to enzyme treatment. The latter is further complicated by the fact that the enzyme 460 used throughout this study was a crude PPL mixture, that contains both protease and 461 lipase constituents (Birner-Grunberger, Scholze, Faber, \& Hermetter, 2003), which 462 could hydrolyse protein and fat components of the dairy powders, respectively.

463 If protein levels of each test material are compared, WPI contains the highest 464 level of protein, yet was found to be a poor inhibitor of S. mutans adhesion to HA. 465 AWPC80 contains less protein than WPI, but exhibited high levels of anti-adhesion 466 activity. Interestingly, SWPC80 contains almost the same level of protein as 467 AWPC80, but was a less effective inhibitor than AWPC80. However, the lactose 
content of SWPC80 was almost three times greater than that of AWPC80, and may 469 have been detrimental to the anti-adhesion activity of this dairy powder. Results from the present study show that lactose promoted adherence of S. mutans to PBS-HA

471 (Table 2), and this may help explain why powders with high lactose contents (WP and 472 DW) exhibited poor anti-adhesion activity. Further to this, it could be speculated that 473 these dairy powders did indeed possess some anti-adhesion activity but this may have 474 been negated by their high lactose content. On the other hand, BMP and CP contained 475 lower levels of protein than both AWPC80 and SWPC80, and also had considerable 476 lactose levels, yet these dairy powders were potent inhibitors of $S$. mutans adherence 477 to HA. It is worthwhile to note that these dairy products (BMP and CP) contain 478 caseins, which are well known to inhibit adherence of $S$. mutans to HA (Vacca-Smith, 479 Van Wuyckhuyse, Tabak, \& Bowen, 1994). It may be the case that whey protein(s) is 480 responsible for the inhibitory activity exhibited by the WPC80s, while casein fractions may be contributing to the anti-adhesion activity caused by BMP and CP. Another 482 possible explanation for the variation in the anti-adherence activity of the various 483 powders may be the differences in fat content, in that in general, only the powders 484 485 with fat contents higher than c. 8\% exhibited high levels of inhibition. Furthermore, it could be speculated that anti-adhesion activity of any dairy powder is due to the 486 presence of both protein and fat, and it may be the case that fat is required in order for 487 protein(s) to effectively associate with HA and consequently reduce adherence of $S$. 488 mutans, as evidenced by the greater level of association of protein to HA in the case 489 of AWPC80 than was observed for WPI.

At the outset of this study, it was anticipated that enzyme treatment would 491 enhance the anti-adhesion efficacy of the dairy powders, as a patent by Brady \& Folan 492 (2003) claimed the adhesion inhibitory properties of a lactose-free commercial whey 
493

494

495

product were activated upon hydrolysis. In addition, it has been reported that certain antimicrobial substances present in milk and dairy-based products (such as peptides and fatty acids) only become active following enzymatic digestion (Lopez-Exposito \& Recio, 2006). However, in the present study the anti-adhesion efficacy of all dairy powders was, in general, reduced following enzyme-treatment for both PBS-HA and S-HA. For the S-HA assays, the efficacy of SWPC80, AWPC80, SWPC35 and CP was slightly (but not necessarily significantly) increased by enzyme treatment at the maximum concentration $\left(125 \mu \mathrm{g} \mathrm{mL}^{-1}\right)$ only. Lower levels of anti-adhesion activity following enzyme treatment may have been due to hydrolysis of proteins and/ or fats, as no consistent trend was observed in order to determine whether protein or fat digestion caused the reduction in efficacy.

A previous investigation by this research group which sought to determine the effect of a range of whey products on the adherence of foodborne pathogens to intestinal cells found that hydrolysis generally increased the inhibitory activity of these test materials (Halpin et al., 2009). However, the study in question employed a model system in which bacterial cells were incubated with epithelial cells, unlike the present study where bacteria were incubated with a mineral surface (hydroxylapatite) in the presence and absence of saliva. Thus, it may be that the efficacy of test materials, and hydrolysates thereof, is dependent on the surface to which microorganisms are adhering to.

Another aspect of the present study was to examine the effect of various dairy powders on the growth of S. mutans. Of the range of test materials, only ET SWPC80 caused a substantial and significant $(P<0.05)$ reduction in the growth of $S$. mutans. SPME/GC analysis confirmed the presence of the free fatty acids butyric $\left(\mathrm{C}_{4}\right)$ and caproic $\left(\mathrm{C}_{6}\right)$ acids in the SWPC80 hydrolysates, and it is possible that other FAs were 
518 present in the hydrolysed product, as milkfat contains a broad spectrum of FAs.

519 Studies by Sprong et al. $(2001,2002)$ have demonstrated the antibacterial activity of

520 milk-lipids. However, the inhibitory activity of ET SWPC80 could equally be due to

521 peptides produced during enzymatic digestion. Peptides liberated from GMP by the

522 action of proteolytic enzymes in PPL may also have contributed to the observed

523 antibacterial effect. A study by Malkoski, Dashper, O’Brien-Simpson, Talbo, Macris,

524 Cross, \& Reynolds (2001) showed that kappacin, a peptide derived from $\kappa$-casein,

525 inhibited growth of plaque-forming bacteria, and although not established here, it is

526 possible such peptides derived from GMP are contributing to the observed

527 antimicrobial activity of ET SWPC80. Alternatively, growth inhibition of S. mutans

528 due to ET SWPC80 may have been the result of a synergistic effect between FAs and

529 peptides released during enzyme treatment. Small peptides exhibiting antimicrobial

530 properties have been proposed as alternatives to antibiotics (Mor, 2003). The oral

531 cavity is considered eminently suitable for the application of such peptides as it

532 provides direct access to bacterial biofilms on non-shedding surfaces (Dashper et al.,

533 2007). Currently, there is considerable commercial interest in the isolation and

534 characterisation of dairy-derived bioactive peptides that can be added to products such

535 as toothpastes, gels and mouth rinses (Aimutis, 2004). Our results show that an

536 enzyme-treated whey product exhibits antibacterial effects, without isolation of

537 individual peptides or FAs. Therefore, an antibacterial agent can be produced from

538 whey, which is available in large quantities and is relatively inexpensive.

539 In conclusion, the results presented here have shown that UT dairy powders

540 are effective inhibitors of S. mutans adherence to both PBS-HA and S-HA. In general,

541 the anti-adhesion efficacy of these dairy powders was, for the most part, reduced

542 following enzyme-treatment. However, some activity was observed following 
enzymatic digestion, in particular for AWPC80, SWPC80, CP and BMP in both PBSHA and S-HA assays. It was also evident that ET SWPC80 is an effective antimicrobial agent active against $S$. mutans. An interesting observation of the present study is that although hydrolysis of a particular whey product may on the one hand increase the antimicrobial activity, it may do so at the expense of the potential antiadhesion activity of the product. In other words, enzyme-treatment of dairy products may enhance antimicrobial activity while suppressing their anti-adhesion efficacy. Nonetheless, this present study has shown that dairy powders, which are natural products and are readily available and relatively inexpensive materials, may offer protection against caries in both normal and dry-mouth contexts.

\section{Acknowledgements}

This work was supported by the national development plan (NDP), with a grant from the food institution research measure (FIRM). We would like to thank Dr. Nessa Noronha, Ms. Maeve O’Connor and Mr. Tristan Rouille for their assistance with experiments.

\section{References}

Aas, J.A., Paster, B.J., Stokes, L.N., Olsen, I. \& Dewhirst, F.E. (2005) Defining the normal bacterial flora of the oral cavity. Journal of Clinical Microbiology, 43, 57215723.

Aimutis, W.R. (2004) Bioactive properties of milk proteins with particular focus on anticariogenesis. Journal of Nutrition, 134, 989S-995S.

Beachey, E.H. (1981) Bacterial adherence: adhesin-receptor interactions mediating the attachment of bacteria to mucosal surface. Journal of Infectious Disease, 143, $325-345$. 
567 Birner-Grunberger, R., Scholze, H., Faber, K. \& Hermetter, A. (2003) Identification

568 of various lipolytic enzymes in crude porcine pancreatic lipase preparations using 569 covalent fluorescent inhibitors. Biotechnology and Bioengineering, 85, 147-154.

570 Brady, D. \& Folan, M. (2003) The use of milk serum apoproteins in the prophylaxis

571 of bacterial and or viral infections. Patent Number US2005042299.

572 Brody, E.P. (2000) Biological activities of bovine glycomacropeptide. British Journal 573 of Nutrition, 84, S39-S46.

574 Clark, W.B. \& Gibbons, R.J. (1977) Influence of salivary components and 575 extracellular polysaccharide synthesis from sucrose on the attachment of 576 Streptococcus mutans 6715 to hydroxylapatite surfaces. Infection and Immunity, 18, $577 \quad 514-523$.

578 Dashper, S.G., Liu, S.W. \& Reynolds, E.C. (2007) Antimicrobial peptides and their 579 potential as oral therapeutic agents. International Journal of Peptide Research and 580 Therapeutics, 13, 505-516.

581 Finlay, B.B. \& Falkow, S. (1997) Common themes in microbial pathogenicity 582 revisited. Microbiology and Molecular Reviews, 61, 136-169.

583 Gaines, S., James, T.C., Folan, M., Baird, A.W. \& O’Farrelly, C. (2003) A novel 584 spectrofluorometric microassay for Streptococcus mutans adherence to 585 hydroxylapatite. Journal of Microbiological Methods, 54, 315-23.

586 Gibbons, R.J., Moreno, E.C. \& Spinell, D.M. (1976) Model delineating the effects of 587 a salivary pellicle on the adsorption of Streptococcus miteor onto hydroxylapatite. 588 Infection and Immunity, 14, 1109-112.

589 Gibbons, R. \& Etherden, I. (1982) Enzymatic modification of bacterial receptors on 590 saliva-treated hydroxyapatite surfaces Infection and Immunity, 36, 52-58. 
591 Halpin, R.M., O’Connor, M.M., McMahon, A., Boughton, C., O’Riordan, E.D., 592 O’Sullivan, M. \& Brady, D.B. (2008) Inhibition of adhesion of Streptococcus mutans 593 to hydroxylapatite by commercial dairy powders and individual milk proteins. 594 European Food Research and Technology, 227, 1499-1506.

595 Halpin, R.M., Brady, D.B., O’Riordan, E.D. \& O’Sullivan, M. (2009) Untreated and 596 Enzyme-Modified Bovine Whey Products Reduce Association of Salmonella 597 typhimurium, Escherichia coli O157:H7 and Cronobacter malonaticus (formerly 598 Enterobacter sakazakii) to CaCo-2 Cells Journal of Applied Microbiology, DOI 599 10.1111/j.1365-2672.2009.04436.x

600 Hayes, M., Ross, R. P., Fitzgerald, G. F., Hill, C. \& Stanton, C. (2006) Casein-derived 601 antimicrobial peptides generated by Lactobacillus acidophilus DPC6026. Applied and 602 Environmental Microbiology, 72, 2260-2264.

603 International Dairy Federation (1987) Standard 9C: determination of fat content of 604 dried milk, dried whey, dried buttermilk and dried butter.

605 International Dairy Federation (1993a) Milk, determination of the nitrogen content: II. 606 Block digestion method (standard 20B) Brussels: International Dairy Federation.

607 International Dairy Federation (1993b) Dried Milk and Cream-Determination of 608 Water Content. Brussels: International Dairy Federation.

609 Johansson, I. (2002) Milk and dairy products: possible effects on dental health. 610 Scandinavian J Nutr, 46(3), 119-122.

611 Kurhonen, H. (2009) Milk-derived bioactive peptides: From science to applications. 612 Journal of Functional Foods, DOI 10.1016/j.jff.2009.01.007.

613 Laemmli, U.K. (1970) Cleavage of structural proteins during the assembly of the head 614 of bacteriophage T4. Nature, 277, 680-685. 
615 Limsong, J., Benjavongkulchai, E. \& Kuvatanasuchati, J. (2004) Inhibitory effect of 616 some herbal extracts on adherence of Streptococcus mutans. Journal of 617 Ethnopharmacology, 92, 281-289.

618 Loesche, W.J. (1986) Role of Streptococcus mutans in human dental decay. 619 Microbiological Reviews, 50, 353-380.

620 Lopez-Exposito, I. \& Recio, I. (2006) Antibacterial activity of peptides and folding 621 variants from milk proteins. International Dairy Journal, 16, 1294-1305.

622 Madureira, A.R., Pereira, C.I., Gomes, A. M. P., Pintado, M.E. \& Malcata, F.X. 623 (2007) Bovine whey proteins: Overview on their main biological properties. Food 624 Research International, 40, 1197-1211.

625 Malkomesius, P. E. \& Nehring, K. (1951) Chemische Untersuchung von 626 Futtermitteln. In: Handbuch der Landwirtschaftlichen Versuchs-und 627 Untersuchungsmethodik, (Band 3). (Ed. Herrmann, R.). Naumann Verlag, Berlin, 628 Germany. pp 15-25.

629 Malkoski, M., Dashper, S.G., O’Brien-Simpson, N.M., Talbo, G.H., Macris, M., 630 Cross, K.J. \& Reynolds, E.C. (2001) Kappacin, a novel antibacterial peptide from 631 bovine milk. Antimicrob Agents and Chemotherapy, 45, 2309-2315.

632 Marshall, K. (2004) Therapeutic applications of whey protein. Alternative Medicine 633 Reviews, 9, 136-156.

634 Mor, A. (2003) Gene-encoded antimicrobial peptides. Peptides, 24, 1645.

635 Noronha, N., Cronin, D. A., O’Riordan, E.D. \& O’Sullivan, M. (2008) Flavouring of 636 imitation cheese with enzyme-modified cheeses (EMCs): Sensory impact and 637 measurement of aroma active short chain fatty acids (SCFAs). Food Chemistry, 106, $638905-913$. 
639 Ofek, I., Hasty, D.L. \& Sharon, N. (2003) Anti-adhesion therapy of bacterial diseases: 640 prospects and problems. FEMS Immunology and Medical Microbiology, 38, 181-191.

641 Schuster, G.S. (1980) Anticaries and antiplaque potential of free fatty acids in vitro 642 and in vivo. Pharmaceutical Therapeutics in Dentistry, 5, 25-33.

643 Sewitz, R.H., Ismail, A.I. \& Bitts, N.B. (2007) Dental caries. Lancet, 369, 51-59.

644 Smith, P.K., Krohn, R.I., Hermanson, G.T., Mallia, A.K., Gartner, F.H., 645 Provenzano,.M.D., Fuzimoto, E.K., Goeka, N.M., Olson, B.T. \& Klend, D.C. (1986) 646 Measurement of protein using bicinchonic acid. Analytical Biochemistry, 150, 76-85. 647 Sprong, R.C., Hulstein, M.F.E. \& van der Meer, R. (2001) Bactericidal activities of 648 milk lipids. Antimicrobial Agents and Chemotherapy, 45, 1298-1301.

649 Sprong, R.C., Hulstein, M.F.E. \& van der Meer, R. (2002) Bovine milk fat 650 components inhibit food-borne pathogens. International Dairy Journal, 12, 209-215.

651 Tarsi, R., Muzzarelli, R.A., Guzman, C.A. \& Pruzzo, C. (1997) Inhibition of 652 Streptococcus mutans adsorption to hydroxylapatite by low-molecular weight 653 chitosans. Journal of Dental Research, 76, 665-672.

654 Vacca-Smith, A.M, Van Wuyckhuyse, B.C., Tabak, L.A. \& Bowen, L.H. (1994) The 655 effect of milk and casein proteins on the adherence of Streptococcus mutans to saliva656 coated hydroxylapatite. Archives of Oral Biology, 39, 1063-1069.

657 Yamanaka, A., Kimizuka, R., Kato, T. \& Okuda, K. (2004) Inhibitory effects of 658 cranberry juice on attachment of oral streptococci and biofilm formation. Oral 659 Microbiology and Immunology, 19, 150-154.

660

661

662 663 


\section{Legends for Figures:}

665 Figure 1: SDS-PAGE showing protein bands present in centrifuged supernatants of 666 sweet whey protein concentrate (WPC) 80, acid WPC 80 and sweet WPC 35, both 667 with and without prior incubation with hydroxylapatite.

668 Lanes: 2= low range markers (range $=6,500-66,000 \mathrm{Da}$ ), 3= AWPC80, 4= AWPC80 669 supernatant after incubation with HA, 5= SWPC80, 6= SWPC80 supernatant after 670 incubation with HA, 7= SWPC35, 8= SWPC35 after incubation with HA and 9= wide 671 range markers (range $=6,500-205,000 \mathrm{Da}$ ).

672 Figure 2: Effects of Enzyme-Treated Sweet WPC80 on the growth of S. mutans, at $6735 \mathrm{mg} \mathrm{mL}^{-1}(\circ), 2.5 \mathrm{mg} \mathrm{mL}^{-1}(\square), 1.25 \mathrm{mg} \mathrm{mL}^{-1}(\Delta), 0.6 \mathrm{mg} \mathrm{mL}^{-1}(\bullet)$ and control growth 674 in the absence of inhibitor (a).

675 Data $=$ mean \pm standard deviation, $n=4$.

676

677

678

679

680

681

682

683

684

685

686

687

688 


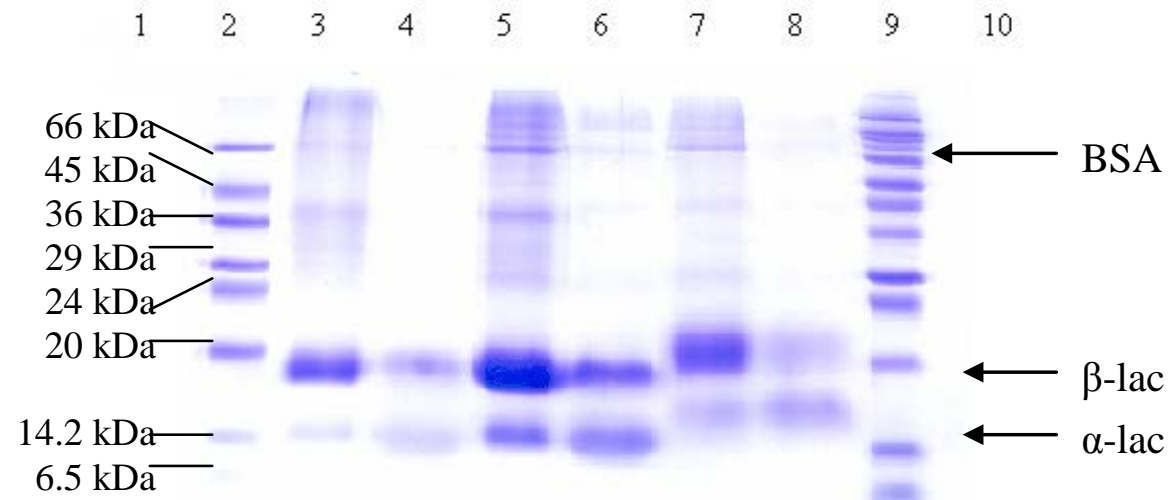

690

691 Footnotes: Bands representing bovine serum albumin (BSA), $\beta$-lactoglobulin and $\alpha$ 692 lactalbumin correspond to the markers labelled at $66 \mathrm{kDa}, 18 \mathrm{kDa}$ and 14k Da, respectively. 
708 Figure 2:

709

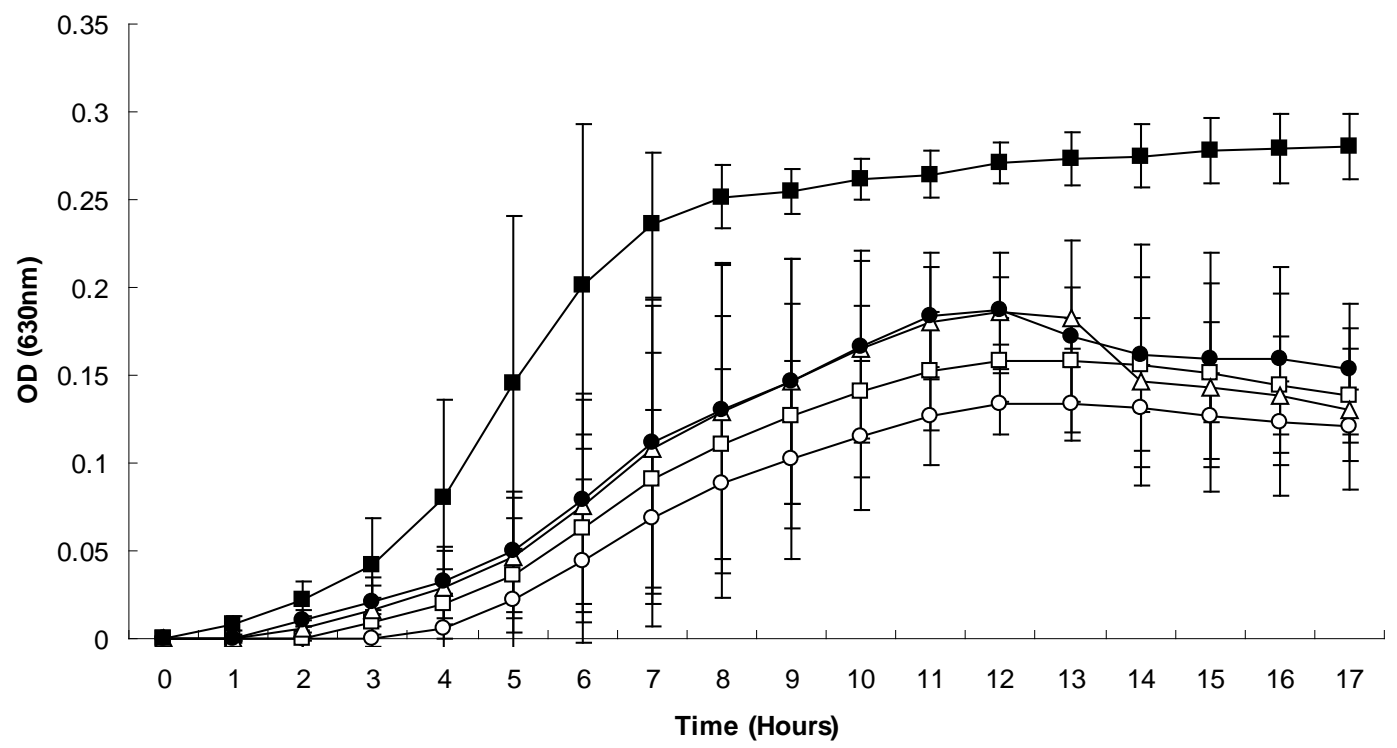

710

711

712

713

714

715

716

717

718

719

720

721

722

723

724 
Table 1: Compositional analysis of dairy powders used in this study (g/ 100g)

\begin{tabular}{ccccccccc}
\hline & SWPC80 & AWPC80 & SWPC35 & WPI & WP & DW & BMP & CP \\
\hline Protein & 75.5 & 78.2 & 34.3 & 86.6 & 12.5 & 13 & 30.2 & 16.4 \\
Fat & 8 & 7.7 & 3.4 & 0.1 & 1 & 1.8 & 10.8 & 49.1 \\
Moisture & 7.5 & 6.3 & 5.4 & 5.8 & 3.1 & 3.5 & 3.9 & 2.1 \\
Ash & 3 & 5.9 & 6.2 & 2.6 & 9.5 & 0.8 & 6.9 & 4.5 \\
Lactose & 6 & 1.9 & 50.7 & 4.9 & 73.9 & 80.9 & 48.2 & 27.9 \\
Total & 100 & 100 & 100 & 100 & 100 & 100 & 100 & 100 \\
\hline
\end{tabular}

727 WPC80, SWPC35= Sweet Whey Protein Concentrate 35, WPI= Whey Protein Isolate,

$728 \mathrm{WP}=$ Whey Powder, DW= Demineralised Whey, $\mathrm{BMP}=$ Buttermilk Powder and $\mathrm{CP}=$

729 Cream Powder.

730

731

732

733

734

735

736

737

738 
Table 2: Proportion of $S$. mutans (\%) not adhering to PBS-HA in the presence of dairy powders at various concentrations.

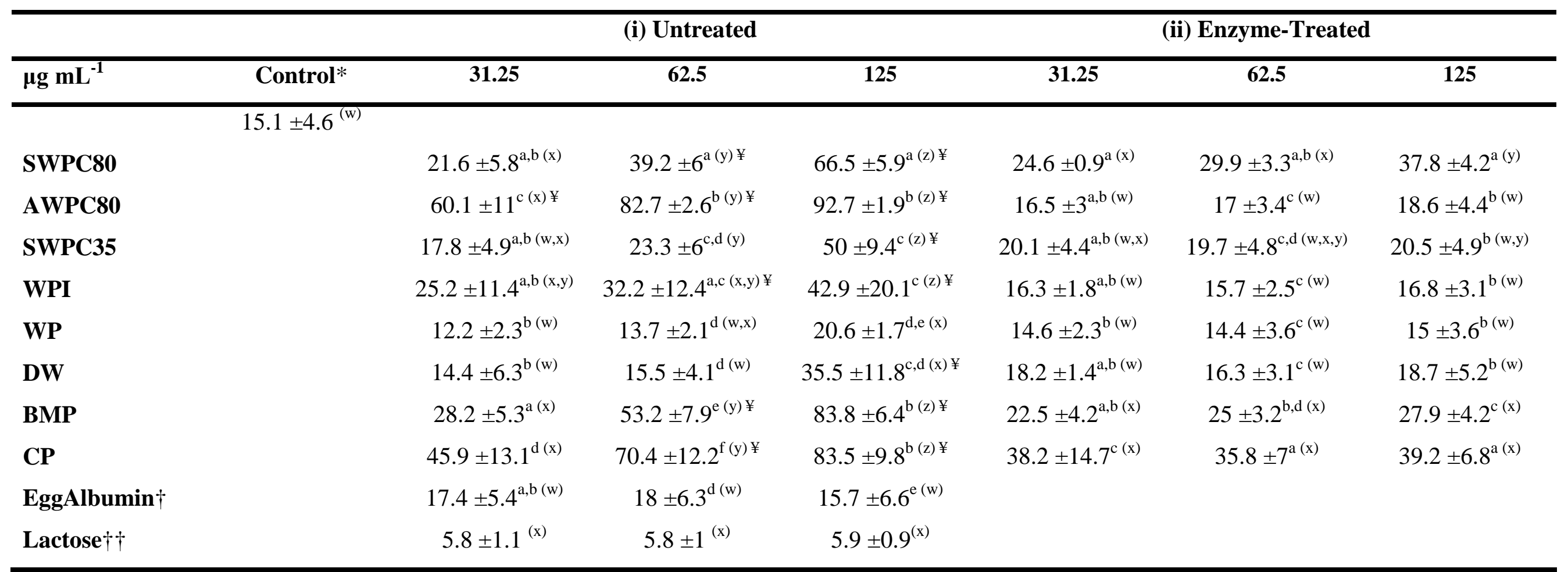

\section{$740 \quad$ Footnotes:}

741 Data presented represent the means ( \pm SD) of 3 replicates. Within each column, means bearing different superscripts (a,b,c etc.) are significantly

$742(P<0.05)$ different. Data within each row bearing different superscripts $(\mathrm{x}, \mathrm{y}, \mathrm{z})$ show significant $(P<0.05)$ differences between concentrations

743 within (i) untreated and (ii) enzyme-treated dairy powders, with control adherence bearing the superscript ' $w$ '.

$744 ¥$ denotes significant difference $(P<0.05)$ between the untreated dairy powder and enzyme-treated form thereof at that particular concentration.

$745 * \mathrm{n}=60, \uparrow=$ egg albumin is included for the sake of comparison only as a protein control. $\dagger \dagger$ lactose $\mathrm{n}=2$.

746 Abbreviations:

747 SWPC80= Sweet Whey Protein Concentrate 80, AWPC80= Acid WPC80, SWPC35= Sweet Whey Protein Concentrate 35, WPI= Whey Protein

748 Isolate, $\mathrm{WP}=$ Whey Powder, $\mathrm{DW}=$ Demineralised Whey, $\mathrm{BMP}=$ Buttermilk Powder and $\mathrm{CP}=\mathrm{Cream}$ Powder. 
Table 3: Proportion of $S$. mutans (\%) not adhering to S-HA in the presence of dairy powders at various concentrations.

\begin{tabular}{|c|c|c|c|c|c|c|c|}
\hline \multirow[b]{2}{*}{$\mu \mathrm{g} \mathrm{mL}{ }^{-1}$} & \multirow[b]{2}{*}{ Control* } & \multicolumn{3}{|c|}{ (i) Untreated } & \multicolumn{3}{|c|}{ (ii) Enzyme-Treated } \\
\hline & & 31.25 & 62.5 & 125 & 31.25 & 62.5 & 125 \\
\hline & $36.8 \pm 7.7^{(w)}$ & & & & & & \\
\hline SWPC80 & & $72.7 \pm 6.2^{\mathrm{a}, \mathrm{b}, \mathrm{c}(\mathrm{x}) ¥}$ & $82.8 \pm 7.3^{\mathrm{a}(\mathrm{x}) ¥}$ & $76.4 \pm 7.8^{\mathrm{a}(\mathrm{x})}$ & $52.8 \pm 8.8^{\mathrm{a}, \mathrm{b}(\mathrm{x})}$ & $60.9 \pm 14.9^{\mathrm{a}(\mathrm{x})}$ & $80.3 \pm 0.5^{\mathrm{a}(\mathrm{y})}$ \\
\hline AWPC80 & & $74.7 \pm 1.7^{\mathrm{a}, \mathrm{b}(\mathrm{x}) ¥}$ & $76.3 \pm 3.5^{\mathrm{a}, \mathrm{b}(\mathrm{x}) ¥}$ & $75.2 \pm 7.1^{\mathrm{a}(\mathrm{x})}$ & $50.9 \pm 7.6^{\mathrm{a}, \mathrm{b}(\mathrm{x})}$ & $57.7 \pm 11.1^{\mathrm{a}(\mathrm{x})}$ & $86.4 \pm 13.7^{\mathrm{a}(\mathrm{y})}$ \\
\hline SWPC35 & & $53.1 \pm 16.7^{\mathrm{d}(\mathrm{x})}$ & $58.7 \pm 12^{\mathrm{c}, \mathrm{d}(\mathrm{x})}$ & $55 \pm 7.6^{\mathrm{b}(\mathrm{x}) ¥}$ & $47.9 \pm 11.3^{\mathrm{a}, \mathrm{b}(\mathrm{x})}$ & $52.2 \pm 10.1^{\mathrm{a}(\mathrm{x})}$ & $78.3 \pm 8.6^{\mathrm{a}(\mathrm{y})}$ \\
\hline WPI & & $50.9 \pm 7.5^{\mathrm{d}(\mathrm{x})}$ & $54.6 \pm 1.5^{\mathrm{c}, \mathrm{d}(\mathrm{x})} ¥$ & $55.2 \pm 7.9^{\mathrm{b}(\mathrm{x})} ¥$ & $37.6 \pm 7.1^{\mathrm{b}(\mathrm{w})}$ & $39.3 \pm 5.9^{\mathrm{a}, \mathrm{b}(\mathrm{w})}$ & $42.4 \pm 2.1^{\mathrm{c}(\mathrm{w})}$ \\
\hline WP & & $61.6 \pm 2.7^{\mathrm{b}, \mathrm{c}, \mathrm{d}(\mathrm{x})} ¥$ & $79.3 \pm 1.8^{\mathrm{a}(\mathrm{y}) ¥}$ & $73.5 \pm 9.3^{\mathrm{a}(\mathrm{x}, \mathrm{y})} ¥$ & $33.9 \pm 3.6^{\mathrm{b}(\mathrm{w})}$ & $40.3 \pm 5.8^{\mathrm{a}, \mathrm{b}(\mathrm{w})}$ & $42.7 \pm 4.9^{\mathrm{c}(\mathrm{w})}$ \\
\hline DW & & $61.4 \pm 4.7^{\mathrm{b}, \mathrm{c}, \mathrm{d}}(\mathrm{x}) ¥$ & $65.1 \pm 3.1^{\text {b,c (x) } ¥}$ & $62.6 \pm 5.1^{\mathrm{a}, \mathrm{b}(\mathrm{x}) ¥}$ & $34.8 \pm 5^{\mathrm{b}(\mathrm{w})}$ & $33.7 \pm 10.8^{\mathrm{b}(\mathrm{w})}$ & $42.8 \pm 6.4^{\mathrm{c}(\mathrm{w})}$ \\
\hline BMP & & $71.8 \pm 1.6^{\mathrm{a}(\mathrm{x})} ¥$ & $63.2 \pm 1.8^{\mathrm{b}, \mathrm{c}, \mathrm{d}(\mathrm{y}, \mathrm{z}) ¥}$ & $59.2 \pm 1.8^{\mathrm{b}(\mathrm{y}, \mathrm{z}) ¥}$ & $44.6 \pm 2.7^{\mathrm{a}, \mathrm{b}(\mathrm{x})}$ & $40.8 \pm 5^{\mathrm{a}, \mathrm{b}(\mathrm{w}, \mathrm{x})}$ & $42 \pm 4.9^{\mathrm{c}(\mathrm{w}, \mathrm{x})}$ \\
\hline $\mathbf{C P}$ & & $58 \pm 10^{\mathrm{c}, \mathrm{d}(\mathrm{x})}$ & $63.1 \pm 15^{\mathrm{b}, \mathrm{c}, \mathrm{d}(\mathrm{x})}$ & $59.2 \pm 7.3^{\mathrm{b}(\mathrm{x}) ¥}$ & $56.3 \pm 7.8^{\mathrm{a}(\mathrm{x})}$ & $52.6 \pm 10.7^{\mathrm{a}(\mathrm{x})}$ & $74 \pm 9.9^{\mathrm{a}(\mathrm{y})}$ \\
\hline EggAlbumin $\dagger$ & & $47.6 \pm 9.2^{\mathrm{d}(\mathrm{x})}$ & $48.9 \pm 7^{\mathrm{d}(\mathrm{x})}$ & $57.3 \pm 13.8^{\mathrm{b}(\mathrm{x})}$ & & & \\
\hline
\end{tabular}

Footnotes:

752 Data presented represent the means ( \pm SD) of 3 replicates. Within each column, means bearing different superscripts (a,b,c etc.) are significantly $753(P<0.05)$ different. Data within each row bearing different superscripts $(\mathrm{w}, \mathrm{x}, \mathrm{y}, \mathrm{z})$ show significant $(P<0.05)$ differences between concentrations

754 within (i) untreated and (ii) enzyme-treated dairy powders, with control adherence bearing the superscript ' $w$ '.

$755 ¥$ denotes significant difference $(P<0.05)$ between the untreated dairy powder and enzyme-treated form thereof at that particular concentration.

$756 * \mathrm{n}=60$, $\dagger=$ egg albumin is included for the sake of comparison only as a protein control. 
Table 4: Initial concentrations of various test materials and quantity of protein in the test material interacting with hydroxylapatite ( $\mathrm{n}=1$ ).

759

\begin{tabular}{|c|c|c|c|c|c|c|}
\hline \multicolumn{7}{|c|}{$\mu \mathrm{g}$ protein per mg HA } \\
\hline $\begin{array}{c}\text { Quantity of Test } \\
\text { Material }\left(\mu \mathrm{g} \mathrm{mL}{ }^{-1}\right)\end{array}$ & SWPC80 & AWPC80 & SWPC35 & WPI & BMP & $\mathbf{C P}$ \\
\hline 62.5 & 5 & 9.1 & 4.2 & 9 & 4 & 3 \\
\hline 125 & 10.5 & 19 & 7.8 & 15 & 8 & 7 \\
\hline 500 & 21.4 & 60.3 & 8 & 27 & 26 & $\mathrm{~N} / \mathrm{D}$ \\
\hline
\end{tabular}

760 Abbreviations:

761 SWPC80= Sweet Whey Protein Concentrate 80, AWPC80= Acid WPC80, SWPC35= Sweet Whey Protein Concentrate 35, WPI= Whey Protein

762 Isolate $\mathrm{BMP}=$ Buttermilk Powder and $\mathrm{CP}=$ Cream Powder 